Technical Information

\title{
Summary of Toxicological Studies on Quinalphos
}

\author{
Regulatory Affairs Department, SDS Biotech K.K.
}

(Received February 20, 1991)

\section{TEST CHEMICAL}

Quinalphos is an organic phosphate insecticide developed by Sandoz, Basle, Switzerland. This chemical has contact and stomach action against a wide range of chewing, sucking and mining pests (orders of Lepidoptera, Diptera, Coleoptera, Hemiptera). It acts rapidly and possesses remarkable properties for long residual action. Although broad-spectrum, it is selective towards certain predators. In Japan, the chemical was registered as an insecticide for arrowhead scale, Unaspis yanonensis (Kuwana), and Indian wax scale, Ceroplastes ceriferus (Fabricius), on citrus in 1987.

Identity, physico-chemical property, solubility and stability are as follows:

Common name: Quinalphos (ISO)

Trade name: Ekalux ${ }^{\circledR}$

Chemical name: $O, O$-diethyl $O$-quinoxalin2-yl phosphorothioate (IUPAC)

Structural formula:

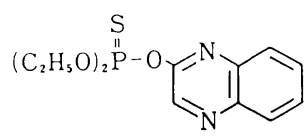

Molecular formula: $\mathrm{C}_{12} \mathrm{H}_{15} \mathrm{~N}_{2} \mathrm{O}_{3} \mathrm{PS}$

Molecular weight: 298.30

Appearance: Colourless crystal powder Specific gravity: $1.235 \mathrm{~g} / \mathrm{ml}\left(20^{\circ} \mathrm{C}\right)$

Melting point: $31-32^{\circ} \mathrm{C}$

Vapour pressure: $2.6 \times 10^{-6}$ Torr $\left(20^{\circ} \mathrm{C}\right)$

Solubility: water; $17.8 \mathrm{ppm}\left(22-23^{\circ} \mathrm{C}\right)$ hexane; slightly soluble toluene, xylene, ether, ethylacetate, chloroform, acetone, methanol, ethanol, acetonitrile DMSO; soluble

Stability: heat, acid, alkali; unstable

\section{ACUTE TOXICITY STUDIES}

The results of acute toxicity studies are summarized in Table 1.

Table 1

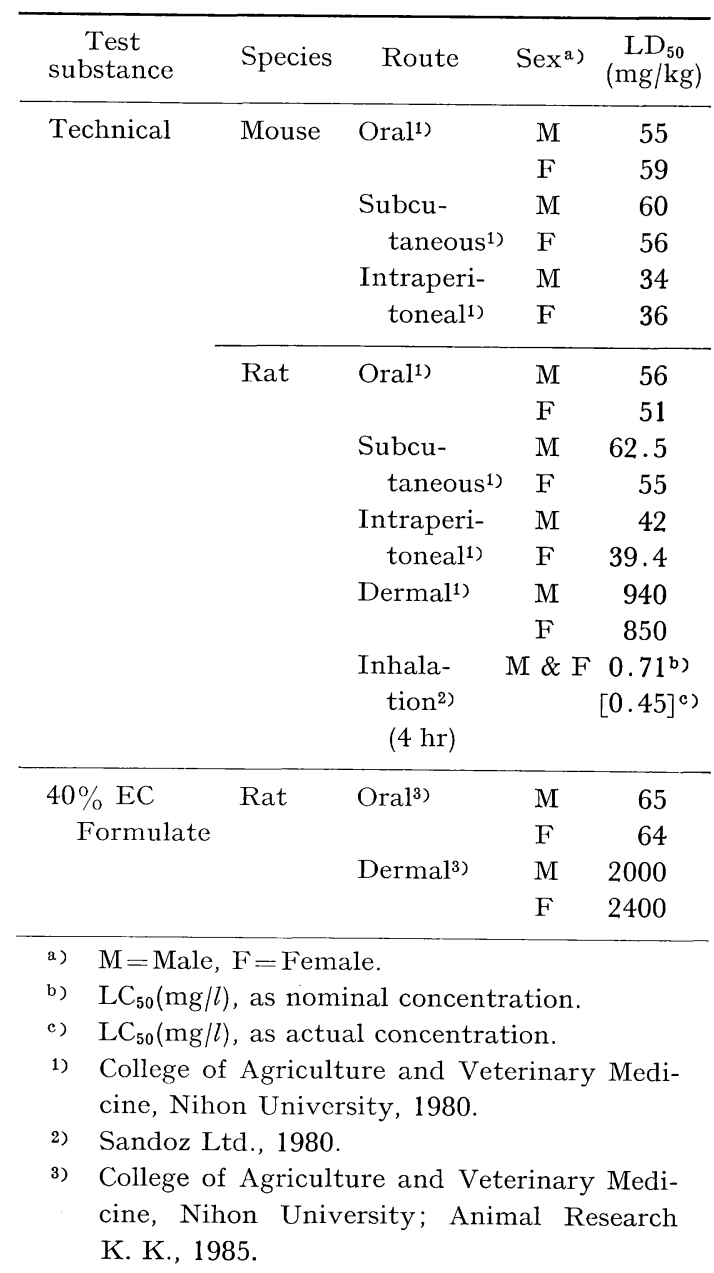




\section{IRRITATION STUDIES}

\section{Primary Eye Irritation}

A $0.1 \mathrm{ml}$ sample of quinalphos technical was instilled into the conjunctival sac of both eyes of 3 male and 3 female New Zealand White rabbits. The eyelids were gently held together for 2 seconds, then, the right eye of each rabbit was washed with a gentle, continuous stream of $20 \mathrm{ml}$ of warm tap water. The eyes were examined after $24,48,72$ hours and after 7 days.

One male died after 21 hours, without any symptoms of organophosphate poisoning before the first eye examination. The other 5 animals developed no irritation in their eyes. Therefore, quinalphos was considered a nonirritant to the rabbit eye.

(Sandoz Ltd., 1978)

\section{Primary Dermal Irritation}

A half milliliter of undiluted quinalphos technical was applied to each treatment area of the intact and abraded skin per animal of 3 male and 3 female New Zealand White rabbits. After 24 hours the bandages were removed and the application sites were washed. Observations were made at 24 and 72 hours after application.

No reactions were observed in the intact skin at 24 and 72 hours after the application, though very slight erythema was found in one animal at 24 hours. In the abraded skin, 3 animals displayed defined erythema and the other 3 only very slight erythema at 24 hours after application; at the 72 hour examination point all reactions disappeared. Based on the test results, quinalphos was not considered to be a primary skin irritant nor a corrosive substance.

(Sandoz Ltd., 1978)

\section{DERMAL SENSITIZATION STUDY}

The maximization method was employed for a dermal sensitization study. A 25\% EC formulate of quinalphos was applied to 20 guinea pigs and a negative control group of 10 animals was provided.

All control animals survived the entire study; in the treated animals, 5 of the 20 died during or after the first patch application, therefore, the 10 control and 15 of the treated animals remained for inspection.

At 24 hours after the challenge application, on day 23 of the test period, 2 of the 10 controls showed a slight redness of the treated area, and 4 of the 15 sensitized animals showed the same symptom. This symptom, a slight redness, in the control animals disappeared after 48 hours. Only one treated animal showed a negligible redness at this time. After 72 hours no reaction was observed.

According to these results, quinalphos was not considered to be a sensitizer.

(Sandoz Ltd., 1980)

\section{ACUTE DELAYED NEUROTOXICITY STUDY}

Quinalphos was orally administered at a dose level of $32 \mathrm{mg} / \mathrm{kg}\left(\mathrm{LD}_{50}=25 \mathrm{mg} / \mathrm{kg}\right)$, by gelatine capsules to 10 chickens protected with atropine and obidoxime chloride. A positive control group received tricresylphosphate.

The first symptoms, mainly limpness and slackness, were observed at 3 hours after the administration. On day 5, all birds were free of symptoms and their weight gain was normal during the 41-day observation period. No paralysis was seen. Histopathological examination revealed that there were no effects relating to quinalphos.

The results indicated that quinalphos has no potential to produce acute delayed neurotoxicity.

(Sandoz Ltd., 1979)

\section{SUBCHRONIC TOXICITY STUDIES}

\section{Thirteen-week Dietary Toxicity Study in Rats}

A group of 35 male and 35 female SpragueDawley rats per dose level was given diets containing quinalphos at concentrations of 0 , 1,3 , and $10 \mathrm{ppm}$ for 13 weeks.

Fasting blood sugar was slightly, but significantly, increased in all treated females and in the males of the low and high doses at the end of the study, but the values were within the normal ranges. The plasma-cholinesterase was depressed in the females of the high dose group, more than in the males. The RBCcholinesterase was less affected. The braincholinesterase was slightly impaired in the $10 \mathrm{ppm}$ females. The liver-cholinesterase showed no significant deviations to the control activity. The relative liver weights were 
somewhat increased in both male and female animals of the high dose group. No other abnormalities or specific findings caused by quinalphos were observed.

In conclusion, since inhibition of cholinesterase and increase of relative liver weights in the high dose group were observed, the noobserved-effect level for this study was considered to be $3 \mathrm{ppm}$ (male: $0.254 \mathrm{mg} / \mathrm{kg} /$ day; female: $0.308 \mathrm{mg} / \mathrm{kg} /$ day).

(University of Bern, Sandoz Ltd., 1978)

\section{Thirteen-week Dietary Toxicity Study in Rats}

Ten male and 10 female Sprague-Dawley rats, for each dose level, were provided and administered quinalphos mixed with their diet at levels of $0,3,12$ and $48 \mathrm{ppm}$ for 13 weeks.

No deaths occurred and no abnormality in clinical signs were observed throughout the testing period. The RBC-cholinesterase and the plasma-cholinesterase were depressed at the dose levels of 12 and $48 \mathrm{ppm}$. The braincholinesterase was depressed in $48 \mathrm{ppm}$ females. No other dose related toxic effects were observed.

The no-observed-effect level for this study was considered to be $3 \mathrm{ppm}$ (male: 0.196 $\mathrm{mg} / \mathrm{kg} /$ day; female: $0.216 \mathrm{mg} / \mathrm{kg} /$ day) because of the cholinesterase depression at the middle and high doses.

(College of Agriculture and Veterinary Medicine, Nihon University, Animal Research K.K., 1981)

\section{CHRONIC TOXICITY AND ONCOGENICITY STUDIES}

\section{Two-year Dietary Toxicity and Oncogenicity Combined Study in Rats}

Each dose group consisted of 55 male and 55 female Sprague-Dawley rats. The dose levels were $0,0.5,2.5$ and $10 \mathrm{ppm}$; these were later raised to 1,3 and $20 \mathrm{ppm}$.

No dose-dependent effects between controls and treated groups were observed in mortality, body weight and hematology. In clinical chemistry, some parameters showed changes but almost all of them were incidental. The cholinesterases were inhibited in the high dose group, the plasma-cholinesterase more than the $\mathrm{RBC}$-cholinesterase, and more so in females than in males. The tissue cholinesterase in brain and liver showed no significant changes compared with the controls. The results of the urinalysis showed no pathological findings.

The organ weights were inconspicuous with exception of the adrenals and the liver, where weights were reduced but not significantly. From the findings in histopathology it was concluded that the distribution of tumors between the groups was within the biological variation and that quinalphos treatment had no carcinogenic effect nor influenced tumorigenesis in any organ or tissue. Quinalphos had not induced specific lesions in any organ or tissue at any dose level.

According to the results of the study, the no-observed-effect level was considered to be $3 \mathrm{ppm}$ (male: $0.189 \mathrm{mg} / \mathrm{kg} /$ day; female: 0.257 $\mathrm{mg} / \mathrm{kg} /$ day) and no oncogenicity was indicated.

(University of Bern, Sandoz Ltd., 1984)

\section{Two Year Dietary Toxicity Study in Dogs}

Groups of 4 male and 4 female beagle dogs were administered quinalphos mixed with their diet at concentrations of $0,0.1,0.3$ and $2.0 \mathrm{ppm}$ The lower doses were later increased to 0.3 and $0.5 \mathrm{ppm}$.

The only relevant effect which could be observed was a slight cholinesterase inhibition in blood plasma at the 2 ppm level.

Under the conditions of this study, the noobserved-effect level was considered to be 0.5 ppm (male: $0.0116 \mathrm{mg} / \mathrm{kg} /$ day; female: 0.0138 $\mathrm{mg} / \mathrm{kg} /$ day) .

(University of Bern, Sandoz Ltd., 1980)

\section{Oncogenicity Study in Mice}

OF-1 mice (74 male and 73 female/dose) were fed $0,0.2,1.0$ and $5.0 \mathrm{ppm}$ of quinalphos for 18 months. Five animals per sex per dose were killed after 29 and 51 weeks and examined.

No significant differences were observed in the body weight, food consumption, behaviour and hematology, between the controls and the treated animals. In the clinical chemistry, the plasma-cholinesterase was clearly inhibited by $50-70 \%$ in both sexes of the high dose group, but not in the middle and low doses. There were no other major changes. In the organ weights, the liver weight was decreased in the relative values of the females 
in all three doses; no other significant differences were noted. In the histopathology, no significant differences in tumor incidence were found at any dose level in this study.

Quinalphos was not considered to be an oncogen.

(University of Bern, Sandoz Ltd., 1984)

\section{REPRODUCTION STUDY}

In a 3-generation reproduction study, including teratogenicity, groups of SpragueDawley rats (30 male and 30 female/dose) were administered quinalphos mixed with their diet at concentrations of $0,1,3$ and $10 \mathrm{ppm}$.

In the results of the reproductive parameters, neither the parent generation nor the following generations showed any signs of disturbances in reproduction. In the teratogenicity investigation, no abnormalities in relation to quinalphos were observed, although one malformation and many deviations, which were within the normal range of the strain used in this study, were observed.

According to the results of this study it was concluded that quinalphos did not influence reproduction and was not teratogenic.

(University of Bern, Sandoz Ltd., 1980)

\section{TERATOGENICITY STUDIES}

\section{Teratogenicity Study in Rats}

Groups of 32 Sprague-Dawley rats were administered quinalphos with peanut oil by oral gavage at dose levels of $0,2.0,5.0$ and 12.0 $\mathrm{mg} / \mathrm{kg}$ daily for 10 consecutive days, from day 6 to 15 of gestation. The animals were killed on day 20 of gestation and the fetuses removed and examined.

Animals at the highest dose level elicited maternal toxicity, tremors in 3 animals, considered likely to be treatment-related, and mean body weight change was reduced from moderately to markedly during the treatment period; but no embryotoxicity or teratogenicity was observed. At the lower doses, treatment with quinalphos did not reveal any signs of toxicity; that is, no maternal toxicity, embryotoxicity or teratogenicity.

Therefore, quinalphos was not considered to be embryotoxic nor teratogenic.

(Hazleton Laboratories Deutschland $\mathrm{GmbH}, 1990)$

\section{Teratogenicity Study in Rabbits}

Groups of 15 New Zealand White rabbits were administered quinalphos with $1 \%$ CMC and $0.2 \%$ Tween 80 by gavage at dose levels of $0,1,4$ and $8 \mathrm{mg} / \mathrm{kg} /$ day from day 6 to 18 of gestation. On day 30 of gestation, the fetuses were removed by cesarean section for examination.

At the high dose level, toxic maternal responses and a number of questionable fetal effects were observed. However, the latter observation might be reasonably ascribed to the maternal toxicity. The lower dose levels did not produce any apparent maternal effects and all dose levels did not suggest any pattern of induced teratogenic activity or adverse fetal effects.

In conclusion, quinalphos was considered to have no teratogenic activity, although the high dose level of quinalphos resulted in maternal toxicity.

(Sandoz Inc., 1979)

\section{MUTAGENICITY STUDIES}

\section{Reverse Mutation Assay}

Escherichia coli WP2 wor A and 5 strains of Salmonella typhimurium, TA 1535, TA 1537, TA 1538, TA 98 and TA 100 were used to evaluate the mutagenic potential of quinalphos. The study was carried out at dose levels of $0,5,10,50,100,500,1000$ and 5000 $\mu \mathrm{g} /$ plate of quinalphos with or without metabolic activation.

Quinalphos induced no appreciable increases in the numbers of revertant colonies of any strain at any dose with or without metabolic activation, compared with those of the corresponding control. Based on the results, quinalphos was not considered to have the capability of inducing reverse mutation.

(Biosafety Research Center, Foods, Drugs and Pesticides, 1981)

\section{Reverse Mutation Assay}

The reverse mutation assay of quinalphos was conducted on Salmonella typhimurium, (5 stains of TA 1535, TA 1537, TA 1538, TA 98 and TA 100) at dose levels of $0,2500,5000$, 10,000 and $20,000 \mu \mathrm{g} /$ plate of quinalphos with or without metabolic activation.

No substantial increases in the number of revertant colonies of any strain were observed 
following the treatment with quinalphos at any dose level in the presence or absence of metabolic activation. It was concluded that quinalphos had no mutagenic potential under the conditions of this study.

(Huntingdon Research Centre, 1980)

\section{DNA Repair Test (Rec-assay)}

The DNA-damaging potential was tested at dose levels of $0,500,1000,5000$ and 10,000 $\mu \mathrm{g} /$ disk of quinalphos using the recombination-wild (H-17) and -deficient (M-45) strains of Bacillus subtilis.

Quinalphos did not cause any inhibitory zone in either strain, even at the highest dose of $10,000 \mu \mathrm{g} /$ disk. It was considered that quinalphos had no DNA-damaging capability.

(Biosafety Research Center, Foods,

Drugs and Pesticides, 1981)

\section{Cytogenetic Test}

To assess the effect of quinalphos on the incidence of cytogenetic damage in rats, total doses of $0,12.5,25$ and $50 \mathrm{mg} / \mathrm{kg}$ bodyweight were administered by intragastric intubation, in two equal doses, separated by an interval of 24 hours. A positive control group was dosed by intraperitoneal injection with Mitomycin $\mathrm{C}$. The rats were killed 6 hours after the second administration of quinalphos and bone marrow cell preparations were examined for the presence of chromosome aberrations in 100 metaphases per rat.

After the second administration, 2 animals of the $50 \mathrm{mg} / \mathrm{kg}$ dose group died. The group mean aberrant metaphase counts in the quinalphos treated group were comparable with the concurrent control values. The positive control group produced the expected increase in the group mean aberrant metaphase counts. It was concluded from the results obtained that quinalphos failed to show any evidence of mutagenic potential in this test.

(Huntingdon Research Centre, 1980)

\section{Micronucleus Test}

The micronucleus test was performed using two ICR mice per sex for each dose level. Each dose was given twice, orally, to the animals with an interval of 24 hours, a single dose being $0,2.5,8$, or $25 \mathrm{mg} / \mathrm{kg}$. The animals were killed 6 hours after the second administration and bone marrow smears were prepared. The frequencies of micronucleated polychromatic erythrocytes (MPEs) were counted.

None of the treated groups showed a significant increase in the frequency of MPEs when compared with the control group. Quinalphos did not prove itself mutagenic in this test.

(Sandoz Ltd., 1979)

\section{GENERAL PHARMACOLOGY}

\section{The Irwin Dose-Range Study}

Quinalphos was assessed for the behavioural and autonomic effects following a single oral dose of $0,1.0,3.0,10 \mathrm{or} 30 \mathrm{mg} / \mathrm{kg}$ to 4 male ICR mice per dose level using an Irwin dose-range test.

Non-specific signs of toxicity were observed in the treated groups. Some neuro-toxic signs, i.e., tonic convulsions and tremor were observed at the highest dose, in which one animal died, at approximately 30 minutes after the administration. The effects were dose-related. The surviving animals had fully recovered by 24 hours after the administration.

(Huntingdon Research Centre Ltd., 1989)

\section{Effects on Cardiovascular and Respiratory Systems}

The effects of quinalphos on some cardiovascular and respiratory parameters in 2 anaesthetised male Sprague-Dawley rats administered intravenously at 4 cumulative doses of $0,0.3,1.0,3.0$ and $10 \mathrm{mg} / \mathrm{kg}$, were examined.

Quinalphos produced inconsistent and transient effects on blood pressure, heart rate and respiration in this study. However, no evidence of a dose-related effect was found. No alteration in the ECG was noted in either animal at any dose level.

(Huntingdon Research Centre Ltd., 1989)

\section{The Slant Test}

The effects of oral administration of quinalphos at $0,1.0,3.0$ and $10 \mathrm{mg} / \mathrm{kg}$ dose levels on muscle atonic activity were investigated using the slant test with 5 male ICR mice per dose level.

Oral administration of quinalphos at doses 
of $1.0,3.0$ and $10 \mathrm{mg} / \mathrm{kg}$ failed to produce muscle atonia in any tested animal.

(Huntingdon Research Centre Ltd., 1989)

\section{Effects on Pupil Diameter and Rectal Tem- perature}

The effects of oral administration of quinalphos on rectal temperature and pupil diameter were assessed in this study with 10 male Wistar rats per dose level. The doses were 0 , $1.0,3.0$ and $10 \mathrm{mg} / \mathrm{kg}$.

A slight decrease in rectal temperature was recorded in vehicle-treated animals. Quinalphos at doses of 3 and $10 \mathrm{mg} / \mathrm{kg}$ appeared to significantly reduce this decrease in rectal temperature. Signs of myosis were observed at all doses of quinalphos. The effects on pupil diameter were clearly dose-related.

(Huntingdon Research Centre Ltd., 1989)

\section{Conclusion}

From the above mentioned results, it was considered that quinalphos affected central and autonomic nervous systems. Myosis was a specific sign following the administration of quinalphos, no other specific signs were observed. No effects on respiratory and cardiovascular systems and skeletal muscles were observed in relation to quinalphos administration.

\section{SUMMARY}

Quinalphos is specified as a deleterious substance since its acute toxicity in mice and rats is high. However, irritation studies in rabbits revealed that quinalphos was a non-irritant to the eye and skin. Quinalphos was considered as a non-sensitizer and was not proved to have the potential to produce acute delayed neurotoxicity.

The depression of cholinesterase activity was observed at high doses in subchronic toxicity studies in rats and it was confirmed in chronic toxicity studies in rats and dogs. In those studies no other major abnormalities related to quinalphos administration were observed and the no-observed-effect levels were defined in the respective studies. No dose-related incidence of tumor was observed in oncogenicity studies in rats and mice, and no potential was revealed in mutagenic studies. In addition, the rat reproductive performance was not effected by quinalphos and no teratogenic potential was indicated in the studies of rats and rabbits.

\section{要 約 \\ キナルホスの毒性試験の概要 \\ 株式会社エス・ディー・エス バイオテック}

農薬刘策室

キナルホスはラットおよびマウスにおケる急性毒性が 高いことから日本では劇物に指定されているが，ウサギ における眼および皮膚に対する刺激性はなく，モルモッ トにおける皮膚感作性も陰性であった。 また，ニワトリ を用いた急性遅発性神経毒性試験の結果も陰性であっ た.ラットを用いた亜急性毒性試験ではコリンエステラ 一ゼ活性の抑制が認められた。ラットおよびイヌを用い た慢性毒性試験では，本所見が確認されたと同時に，各 試験での最大無作用量が示された. ラットおよびマウス における発癌性試験および細菌等を用いた変異原性試験 の結果は陰性であった，加えて，ラットにおける繁殖性 に対する影響も認められず，ラットおよびウサギを用い た催奇形性試験においても本剤は催奇形性をもたないと 判定された。

\section{Contact}

Regulatory Affairs Department, SDS Biotech K.K., 2-12-7 Higashi Shimbashi, Minato$\mathrm{ku}$, Tokyo 105, Japan

\section{問合せ}

（株）エス・ディー・エス バイオテック 農薬対策室

干105 東京都港区東新橋 2-12-7 